Maja Dimić

Fakultet za strateški i operativni menadžment, Beograd maja.dimic@fpsp.edu.rs

Lidija Barjaktarović

Univerzitet Singidunum lbarjaktarovic@singidunum.ac.rs

Prevod obezbedio

autor
VLASNIČKA TRANSFORMACIJA BANKARSKOG SEKTORA U ZEMLJAMA JUGOISTOČNE EVROPE

Rad je deo doktorske disertacije "Analiza nivoa koncentracije u banakarskom sektoru i u sektoru osiguranja u zemljama centralne i istočne Evrope", Univerzitet Singidunum, Beograd 2015, autor: Maja Dimić, mentor: prof. dr Lidija Barjaktarović.

Ovaj istraživački rad deo je projekta "Poboljšanje konkurentnosti Srbije u procesu pristupanja Evropskoj uniji“, br. 47028, sprovedenog u periodu od 2011. do 2016. godine, koji je finansiralo Ministarstvo nauke i tehnološkog razvoja Republike Srbije.

\title{
Rezime
}

U poslednje tri decenije, pa sve do izbijanja ekonomske krize, na svetskom finansijskom tržištu bio je zastupljen trend usmeren ka konsolidaciji finansijskih tržišta. Globalni fenomeni, tehnološke inovacije, liberalizacija kao i deregulacija tržišta bili su faktori koji su olakšali proces spajanja i pripajanja u finansijskom sektoru. U bankarskom sektoru jugoistočne Evrope, u turbulentnom poslovnom okruženju, svakodnevno se dešavaju promene koje primoravaju banke da se prilagođavaju nastaloj situaciji. Proces restrukturiranja odnosi se na brojne aktivnosti kojima bankarski sektor menja postojeću vlasničku strukturu i strategije poslovanja u cilju maksimiziranja profita i poboljšanja efikasnosti poslovanja. Cilj rada je da prikaže proces restrukturiranja banaka u regionu jugoistočne Evrope pre i za vreme izbijanja ekonomske krize, kao i da ukaže na činjenicu da je vlasnička transformacija praćena rastućim učešćem stranog vlasništva uticala na prekomponovanje tržišne strukture kao i na rast njegovog učešća u ukupnom kapitalu (bilansnoj sumi).

Ključne reči: bankarski sektor, vlasnička transformacija, zemlje jugoistočne Evrope 


\section{OWNERSHIP \\ TRANSFORMATION OF \\ THE BANKING SECTOR IN SEE COUNTRIES}

\author{
Maja Dimić \\ Faculty for Strategic and \\ Operational Management, \\ Belgrade \\ maja.dimic@fpsp.edu.rs
}

Lidija Barjaktarović

Singidunum University lbarjaktarovic@singidunum.ac.rs

\begin{abstract}
Translation provided by the author
\end{abstract}

The research is a part of the PhD dissertation under the title "Analysis of the level of concentration in the banking and insurance sector in the countries of Central and Eastern Europe" approved and accepted by Singidunum University Belgrade in 2015, author: Maja Dimić, mentor: prof. dr Lidija Barjaktarović

This research paper was a part of the project "Advancing Serbia's Competitiveness in the Process of EU Accession", no. 47028, in the period 2011-2016, financed by the Serbian Ministry of Science and Technological Development.

\section{Summary}

Consolidation of financial markets used to be the trend on the global market in the previous three decades up to the recent economic crisis. Global phenomena, technological innovation, liberalization and deregulation used to be the factors which made the process of mergers and acquisitions in the financial sector much easier. In the banking sector of Southeastern Europe, in a turbulent environment, changes are occurring on a daily basis, forcing the banks to adjust to the new situation. The restructuring process is related to the various activities whose main result is the changed ownership structure and business strategy with a view to maximizing profitability and improving efficiency. The aim of our research is to present the banks' restructuring processes in the region of Southeastern Europe before and during the crisis, as well as to stress the fact that the ownership transformation, followed by an increased share of foreign ownership, affected the changes in the market structure and its share in total equity (in the banking balance sheet size).

Keywords: banking sector, ownership transformation, SEE countries 


\section{Uvod}

U razvijenim finansijskim sistemima, $\mathrm{u}$ turbulentnom poslovnom okruženju, svakodnevno se dešavaju promene koje primoravaju finansijske institucije da se brzo prilagođavaju nastaloj situaciji. Proces restrukturiranja, kao sastavni element tranzicije, odnosi se na veliki broj aktivnosti kojima kompanije menjaju postojeću vlasničku strukturu i strategije poslovanja u cilju: maksimiziranja profita, poboljšanja efikasnosti poslovanja, kreiranja sinergije (dodatne vrednosti), rasta kompanije (dugoročno povećanje veličine kompanije), povećanja poslovnih aktivnosti, uštede na troškovima, smanjenja rizika poslovanja, ulaska na nova tržišta, poboljšanja u upravljanju (menadžmentu) kompanije.

$\mathrm{U}$ tom kontekstu, autori $\mathrm{u}$ istraživanju polaze od hipoteze da je proces restrukturiranja bankarskog sektora, koji je praćen povećanjem učešća stranog vlasnišstva, imao uticaj na prekomponovanje tržišne strukture kao i na rast njegovog učešća u ukupnom kapitalu (bilansnoj sumi) u regionu jugoistočne Evrope. Autori su ispitivali validnost hipoteze koristeći sledeće indikatore: merdžeri i akvizicije u bankarskom sektoru (brojčano, vrednosno i vlasnički), učesnici na bankarskom tržištu (brojčano/vlasnički), kriterijumi razvijenosti bankarskog sektora (ukupna bilansna suma/kapital) u periodu 2007-2012. Teritorijalno polazište empirijskog istraživanja su zemlje koje je Međunarodni monetarni fond klasifikovao i definisao kao zemlje regiona jugoistočne Evrope [IMF, World Economic Outlook]. Istraživanjem su obuhvaćene zemlje regiona jugoistočne Evrope sa sličnim nivoom ekonomske razvijenosti, i to: Srbija, Hrvatska, Bosna i Hercegovina, Crna Gora, Bivša Jugoslovenska Republika Makedonija (u daljem tekstu Makedonija), Rumunija, Bugarska i Albanija.

Rad je podeljen u tri celina. U prvom delu rada autori daju pregled učesnika na bankarskom tržištu u regionu jugoistočne Evrope, a zatim i teorijski prikaz faza razvoja bankarskog sektora u posmatranom regionu. U delu tri urađeno je empirijsko istraživanje vlasničkih transformacija kako pre tako i za vreme izbijanja svetske ekonomske krize.

\section{Učesnici na bankarskom tržištu u regionu jugoistočne Evrope}

$\mathrm{Na}$ svetskom finansijskom tržištu broj banaka se smanjuje iz godine $u$ godinu usled pojave novih (merdžeri i akvizicije) ili razvoja već postojećih finansijskih institucija, kao što su osiguravajuće i lizing kompanije i penzioni fondovi. Drugim rečima, savremena finansijska tržišta karakteriše proces ukrupnjavanja finansijskih institucija, gde se jedna kreditna institucija pored bankarskih poslova bavi i/ li poslovima osiguranja, pružanjem lizing usluga, berzanskim posredovanjem i poslovima penzionih fondova. U tom kontekstu, iako postoji mali potencijal za rast poslovanja na tržištima Evrope, pojavljivanjem novih banaka sa savremenim poslovnim modelima i nefinansijskih institucija koji ulaze i preuzimaju deo bankarskog tržišta, predstavlja veliki izazov za postojeće banke [Macut, 2014, str.198-199].

Ulazak i izlazak banaka iz finansijskog sistema, odnosno povećanje ili smanjenje broja banaka, uslovljeno je brojnim faktorima sa kojima se banke suočavaju kako prilikom osvajanja novog tržišta tako i u svakodnevnom poslovanju:

- makroekonomski indikatori (nivo bruto domaćeg proizvoda, stopa inflacije, nivo stranih direktnih investicija, nivo kamatnih stopa, spoljnotrgovinski bilans, javni dug zemlje);

- monetarna politika koju sprovodi Centralna banka (stimuliše ili ograničava ulazak novih "igrača" na tržište);

- socijalni faktori (stopa nezaposlenosti i nivo realnih plata u sektoru);

- rizik zemlje;

- politička situacija;

- administrativne barijere i drugi faktori.

Sa povećavanjem broja merdžera i akvizicija, kao i pojave recesije na finansijskom tržištu, $\mathrm{u}$ proteklih nekoliko godina $\mathrm{u}$ finansijskom sektoru Evropske unije došlo je do smanjenja broja kreditnih institucija [ECB, EU Banking Structure, 2010]. Na kraju 2011. bankarsko tržište zemalja EU27 brojalo je 8.060 kreditnih institucija, što je u poređenju sa 2009. godinom manje za 3,5\%.

Iskustva zemalja koje su prošle kroz tranzicioni period (primer je Mađarska) pokazuju da se nakon 


\section{Introduction}

In the developed financial systems, in a turbulent business environment, changes are occurring on a daily basis, forcing the financial institutions to quickly adjust to the new situation. The restructuring process, as an integral aspect of transition, is related to a huge number of activities, whereby the companies change the existing ownership structure and business strategies in order to: maximize profit, improve efficiency, create the synergy (added value), expand the company (longterm increase of the company's size), boost the business activities, cut the costs, mitigate the business risks, enter new markets, improve the management within the company.

Accordingly, the main hypothesis of our research is that the process of restructuring the banking sector, which is followed by an increased share of foreign equity, had an impact on the changed market structure and its share in total equity (in banking balance sheet size) in the region of Southeastern Europe. The authors examined the validity of the hypothesis by referring to the following indicators: mergers and acquisitions (M\&A) in the banking sector (in terms of their number, amount in EUR million, and ownership) in the period between 2007 and 2012. The area of the empirical research includes the countries which are classified by the International Monetary Fund (IFC) as countries of Southeastern Europe (hereafter to be referred to as SEE) [IMF, World Economic Outlook]. The research covered the SEE countries which have the similar level of economic development, i.e. Serbia, Croatia, Bosnia and Herzegovina (B\&H), Montenegro, Former Yugoslav Republic of Macedonia (hereafter to be referred to as Macedonia), Romania, Bulgaria and Albania.

The research consists of 3 chapters. In the first chapter, the authors list the participants on the banking market in the SEE region. In the second chapter the authors provide a theoretical review of the stages of development of the banking sector in the SEE region. The third chapter features the empirical research results concerning the ownership transformation before and during the global economic crisis.

\section{Participants in the banking market in the SEE region}

The number of business banks has been decreasing due to the occurrence of new financial institutions (through M\&A) or the development of the existing ones, such as insurance and leasing companies and pension funds. Accordingly, modern financial markets are characterized by the process of consolidated financial institutions, where one credit institution expands its business in addition to banking operations to include insurance business, leasing services, brokerage or intermediation in pension funds operations. In this context, despite the small growth potential on the European market, the appearance of new banks with modern business models and nonfinancial institutions entering and taking over a part of the banking market, poses a major challenge for the existing banks [Macut, 2014, pp. 198-199].

The entrance and exit of banks from the financial system, i.e. the increase or decrease in the number of banks is determined by numerous factors that the banks are facing when expanding to other markets or in their everyday business operations:

- Macroeconomic indicators (level of gross domestic product/GDP/, inflation rate, level of foreign direct investments /FDI/, level of interest rates, export-import balance, public debt of the country);

- Monetary policy implemented by the central bank (stimulating or limiting the entrance of new players on the market);

- Social factors (unemployment rate and level of real salaries in the sector);

- Country risk;

- Political situation;

- Administrative barriers and other factors. The number of business banks in the financial market of European Union (EU) has been decreasing, as a result of $M \& A$ and the financial market recession [ECB, EU Banking Structure, 2010]. At the end of 2011, the banking market of EU 27 counted 8,060 credit institutions, which is by $3.5 \%$ less compared to 2009 .

The experience of the countries which passed through the transition period (e.g. Hungary) showed that after the establishment 
formiranja stabilnog bankarskog sektora nastavlja razvoj finansijskog sistema, odnosno drugih finansijskih institucija kao što su osiguravajuće kompanije, penzioni i investicioni fondovi. Kada je reč o broju učesnika na bankarskom tržištu u regionu jugoistočne Evrope, u proteklih nekoliko godina nisu zabeležene prevelike oscilacije. Pre nastupanja finansijske krize najviše banaka bilo je na tržištu Rumunije (više od 40), Srbije i Hrvatske (oko 30), dok je najmanji broj zabeležen u Crnoj Gori i Albaniji (između 10 i 15) [ BSCEE 2010, BSCEE 2011].

Iako je bankarski sektor u uslovima svetske ekonomske krize odigrao važnu ulogu i pružio podršku drugim institucijama, proteklih godina nije bio izolovan na finansijskom tržištu. Negativni efekti krize vidljivi su u 2009. godini kada je u zemljama jugoistočne Evrope zabeleženo stagniranje broja banaka koje posluju na ovim tržištima (izuzetak su Rumunija i Srbija u kojima je po jedna banka napustila tržište). Ni u 2010. nisu zabeležene velike promene, u Srbiji i Bosni i Hercegovini po jedna banka je izašla sa tržišta. Na kraju 2012. godine najveći broj učesnika na bankarskom tržištu imala je Rumunija.

\section{Faze razvoja bankarskog sektora $u$ zemljama jugoistočne Evrope}

Bankarsko tržište jugoistočne Evrope je u poređenju sa bankarskim sistemom Evropske unije relativno malo i nedovoljno razvijeno [Barjaktarović i Paunović, 2012, str. 85]. Banke su devedesetih godina XX veka izgubile svoju osnovnu ulogu, funkciju mobilisanja slobodnih sredstava i njihovo plasiranje $u$ profitabilne projekte, te je poverenje javnosti u bankarski sektor izgubljeno zbog nemogućnosti deponenata da raspolažu svojim sredstvima, kao i zbog loših iskustava sa nekoliko piramidalnih banaka tokom te decenije [Erić Jović, 2012, str.6]. Iz tog razloga, na bankarskom tržištu regiona jugoistočne Evrope sprovedene su reforme koje su se ogledale $\mathrm{u}$ privatizaciji državnih banaka i otvaranju domaćeg finansijskog sektora stranim investitorima. U tranzicionim ekonomijama uočavaju se tri faze u razvoju bankarskog sektora.

Prva faza je uspostavila sistem komercijalnih banaka kao akcionarskih kompanija umesto monobankarskog sistema. Evropske privrede u tranziciji predstavljaju poseban slučaj, pošto su bankarski sistemi u svim ovim državama evoluirali iz jedne institucije-monobanke koja je bila zadužena, kako za monetarnu politiku, tako i za komercijalne bankarske aktivnosti.

U tri zemlje predmet analize - Albanija, Bugarska i Rumunija je postojao klasičan socijalistički monobrankarski sistem prethodno opisan, s obzirom da je svojina bila državna. Proces transformacije je podrazumevao $u$ prvoj fazi, da se od pomenute jedne državne banke formiraju tri državne banke - centralna, komercijalna i investiciona. $U$ narednom koraku se formiralo više komeracijalnih banaka u državnom vlasništvu.

Zemlje predmet analize koje su pripadale SFRJ nisu imale klasičan socijalistički monobrankarski sistem, s obzirom na to da je postojalo samoupravno socijalističko društvo, a "model jugoslovenske privrede i društvenog sistema je postavljen kao da je Jugoslavija izolovana zemlja. Platni promet se odvijao preko državne institucije - Službe društvenog knjigovodstva, i to samo $u$ unutrašnjem prometu društvenog sektora, ali ne i u sektoru stanovništva, ne u prometu društvenog sektora prema inostranstvu, niti u sektoru individualne privrede. Zadatak banaka u Jugoslaviji je bio da obezbede optimum sredstava za prave namene i u pravo vreme po najpovoljnijoj ceni." Banke su poslovale po klasičnim principima likvidnosti, solventnosti i boniteta [Čolanović u izoru Matić 2014], tj. plasirale su kredite u skladu sa količinom depozita koje su prikupile. Cilj poslovanja banke je bio ostvariti dohodak u sferi društvene reprodukcije. Narodna banka FNRJ je imala emisionu, kreditnu i deviznu funkciju. Služba društvenog knjigovodstva / SDK/ (1959-1991), a potom promenjenog naziva Zavod za obračun i plaćanje /ZPP/ (19922002) je činila strukturu bankarskog sistema - obavljala je poslove od opšteg društvenog interesa, platnog prometa, vršila kontrolu raspolaganja i trošenja društvenih sredstava itd. Opisane razlike $\mathrm{u}$ analiziranim zemljama su podrazumevale drugačiji operativni pristup procesu transformacije bankarskog sektora.

Drugi korak je predstavljao restrukturiranje bankarskih portfolija i rekapitulaciju banaka. Proces tranzicije obeležio je formiranje dvoslojnih 
of a stable banking sector, the overall financial system undergoes some positive developments, i.e. other financial institutions such as insurance companies, pension and investment funds. If we analyze the number of participants on the SEE banking market in the previous years, it can be concluded that there has been no significant fluctuations. Before the crisis broke out, there were the largest number of banks was present in Romania (above 40), followed by Serbia and Croatia (with 30 banks on average), while the lowest number was recorded in Montenegro and Albania (between 10 and 15) [BSCEE 2010, BSCEE 2011].

Although the banking sector played an important and supportive role to other financial institutions during the crisis, it was not isolated from fluctuations on the financial market in the past years. Moreover, the negative effects of the crisis were visible in 2009 when the SEE countries recorded the stagnation in a number of banks operating in this region (exceptions are Romania and Serbia where only one bank left each market). Furthermore, there were no drastic changes in 2010 either, given that in Serbia and B\&H only one bank left each market. Finally, Romania had the biggest number of participants on the banking market in 2012.

\section{Stages of banking sector development in the SEE countries}

The banking market of SEE is relatively small and undeveloped compared to the EU market [Barjaktarović and Paunović, 2012, p. 85]. In the 1990s banks lost their main role of collecting the available funds and investing them in profitable projects, which resulted in a loss of trust in the banking sector, due to the fact that depositors i.e. clients of the banks could not dispose of their funds without limitations, as well as due to the negative experiences with several pyramidal banks during that decade [Erić Jović, 2012, p. 6]. Accordingly, the SEE banking market implemented the reforms which resulted in the privatization of state owned banks and opening of the domestic financial market to foreign investors. In transition economies there are three stages of the banking sector's development.

The first stage established the system of commercial banks as shareholding companies instead of the mono-banking system. The European economies in transition represent a specific case, due to the fact that the banking systems in those countries evolved from a single mono-bank-institution which used to be in charge of both the monetary policy and commercial banking activities.

The three countries that are the subject of our analysis - Albania, Bulgaria and Romania, used to have the classic socialist mono-banking system described in the previous paragraph, given that the property was state-owned. In the first stage the transformation process implied the formation of three state banks from the above mentioned state-owned bank - i.e. the formation of the central, commercial and investment bank. In the subsequent step several state-owned commercial banks were formed.

The countries subject of our analysis which belonged to Social Federal Republic of Yugoslavia (SFRY) did not have the classic socialist mono-bank system, given the existence of the self-governing society, and the model of the Yugoslav economy and society which was based and established on the fact that Yugoslavia was an isolated country. Domestic payments between legal entities used to be executed through a state institution - i.e. the Social Accounting Service (which did not cover retail and international payments). The task of Yugoslav banks was to provide the optimal level of funds for the right purposes, in due time, at the most favorable price. The banks used to perform business in accordance with the classic principles of liquidity, solvency and credibility [Čolanović in the source Matić 2014], meaning that the banks' limits for granting the loans were in accordance with their collected deposits. The aim of the bank was to achieve income in the area of social reproduction. The National Bank of FNRY performed the issuing, credit and foreignexchange function. The Social Accounting Service (1995-1991) which changed its name into the Department of Accounting and Payments (1992-2002) was a part of the banking system's structure - it performed the activities important for the general social interest, payments, control and monitoring of the social funds' spending. The described differences in the analyzed countries implied a different operational approach to the 
bankarskih sistema sa posebnim bankarskim subjektima. Da bi bilo izvršeno uspešno restrukturiranje banaka, moraju postojati sledeći preduslovi [Dinkić i Jelašić, 2001]:

- unutrašnja politička podrška za realizaciju ovog procesa;

- razvoj opšte ekonomske situacije u zemlji;

- -finansijska podrška međunarodne zajednice naporima da izvrše restrukturiranje banaka;

- raspoloživost odgovarajućih finansijskih sredstava za ove namene;

- primena pravnog i institucionog okvira za regulisanje potraživanja i likvidaciju preduzeća, odnosno banaka;

- odgovarajući finansijski i kadrovski potencijal državne agencije za sanaciju banaka;

- socijalni program za zaposlene koji ostanu bez posla u bankarskom sektoru;

- koordinacija sa ministarstvima za privatizaciju i finansije.

Treća faza razvoja bankarskog sektora u zemljama u tranziciji uključivala je privatizaciju bankarskog sektora (prenos vlasništva od države ka privrednim subjektima). Tako se 2000-tih javlja interesovanje stranih investitora za bankarsko tržište u zemljama u regionu. Neki od kriterijuma za ulazak stranih investitora na bankarsko tržište regiona bili su: niži nivo bruto domaćeg proizvoda po glavi stanovnika, veći procenat obrazovanog stanovništva, razvijena kreditna i finansijska tržišta, niska stopa inflacije, projekcije visokog ekonomskog rasta i ostvarivanje visokog prinosa. Poslednji kriterijum (ostvarivanje visokog prinosa) odigrao je ključnu ulogu u donošenju odluke za ulazak stranih investitora na bankarsko tržište regiona. Kako bi ostvarili dominaciju na tržištu i postali što konkurentniji, strani investitori su se opredeljivali za ulazak na ovo finansijsko tržište. Budući daje ovajdeo finansijskog sistema pružao inostranim bankama mogućnost ostvarivanja i maksimiziranja profita, interesovanje su prvo pokazale austrijske banke, a zatim nemačke, italijanske i francuske.

Ulazak inostranih investitora u bankarski sektor u regionu uključivao je nekoliko očekivanih koristi [Dinkić i Jelašić, 2001]:

- uvođenje novih bankarskih tehnologija i finansijskih inovacija;

- mogućnost ekonomije obima i vrste posla;
- poboljšanje konkurentskog ambijenta;

- poboljšanje infrastrukture finansijskog sistema;

- privlačenje stranih investicija.

Empirijske studije u ovoj oblasti su pokazale da su u zemljama u razvoju banke sa većinskim stranim kapitalom mnogo efikasnije poslovale od domaćih konkurenata. Bonin [2004] u svom radu na uzorku od 225 banaka u privredama $\mathrm{u}$ tranziciji pokazuje da su banke $\mathrm{u}$ stanom vlasništvu troškovno efikasnije i da pružaju viši nivo usluge nego domaće banke. Ovu tezu potvrđuju i Kraft i Hofler [2006] koji u svom radu ističe efikasnost poslovanja banaka u većinskom stranom vlasništvu u Hrvatskoj.

\section{Privatizacija bankarskog sektora $\mathbf{u}$ regionu jugoistočne Evrope}

$\mathrm{Na}$ početku procesa restrukturiranja finansijskog sistema $\mathrm{u}$ regionu centralne $\mathrm{i}$ istočne Evrope zabeležena je dominacija banaka sa većinskim državnim vlasništvom. Dodatno, primećeno je da se domaći vlasnik (najčešće država) nije adekvatno starao o svojoj imovini što je za posledicu imalo promenu vlasničke strukture i povećanje učešća stranih investitora u finansijskom sektoru regiona. U jednom broju ekonomskih sistema, posebno kod zemalja $\mathrm{u}$ regionu, uočava se trend smanjenja udela državnih banaka u sistemu, koji je posledica: otvaranja nacionalnog bankarskog tržišta za domaći i strani privatni kapital, gašenja gubicima opterećenih banaka u državnom vlasništvu i sprovođenja politike privatizacije [Marinković i Ljumović, 2011, str.190].

Berger [2007] navodi prednosti i nedostatke $\mathrm{u}$ vezi sa ulaskom stranih banaka (finansijskih institucija) na nova tržišta. Neke od komparativnih prednosti stranih banaka su:

- Multinacionalne aktivnosti banke u stranom vlasništvu omogućavaju joj da diversifikuje rizike na više regiona u kojima posluje čime se smanjuju troškovi upravljanja rizicima.

- Banke prate glavne korporativne klijente i osnivaju filijale u državama u kojima njihovi klijenti proširuju poslovne aktivnosti.

- Pokazalo se da geografska diversifikacija multinacionalnih banaka doprinosi poboljšanju uspešnosti i efikasnosti poslovanja. 
banking sector's transformation process.

The second step involved the restructuring of the banks' portfolios and the closing of banks. The transition process resulted in establishing the dual banking systems with separate banking entities. In order to achieve a successful restructuring of banks, the following preconditions must be met [Dinkić and Jelašić, 2001]:

- Internal political support for the execution of this process;

- Development of the general economic situation in the country;

- Financial support by the international community to the restructuring of banks;

- Availability of proper financial resources for this purpose;

- Application of the legal and institutional frame for collecting of receivables and liquidation of companies i.e. banks;

- Appropriate financial and human potential within the state agency for banks' rehabilitation;

- Social program for employees who lose their job in the banking sector;

- Coordination with the ministries for privatization and finance.

The third stage of development of the banking sector in transition countries included the privatization of the banking sector (transfer of ownership from the state to business entities). This generated the interest of foreign investors for the banking market in the SEE countries during the 2000s. Some of the relevant criteria for the entrance of foreign investors onto the banking markets in the region were: lower level of GDP per capita (GDPpc), higher percentage of educated population, developed credit and financial markets, low inflation rate, projections of high economic growth and high achieved revenues. The last criteria (achievement of high revenues) had the key role in making the decision concerning the entrance of foreign investors onto the regional banking market. Furthermore, foreign investors opted to enter this financial market in order to achieve market domination and the highest competitiveness possible. Given that this part of the financial system granted foreign banks the possibility to yield and maximize their profit, the Austrian banks were the first to show the interest, followed by the German, Italian and French banks.
The entrance of foreign investors into the banking sector in the region included several expected benefits [Dinkić and Jelašić, 2001]:

- Introduction of new banking technologies and financial innovation;

- Possibility of economy of scale and type of business;

- Improvement of the competitive environment;

- Improvement of the financial system infrastructure;

- Attraction of foreign investments (FI).

Empirical research conducted in this area confirmed that foreign-owned banks in the developing countries had been doing business more efficiently compared to their domestic competitors. Bonin [2004] stressed that foreign-owned banks (a sample of 225 banks) in transition economies were cost-efficient and offered a higher level of service quality compared to domestic banks. This has also been confirmed for the Croatian market in the research done by Kraft and Hofler [2006].

\section{Privatization of the banking sector in the SEE region}

The beginning of the process of restructuring the financial system in the region of Central and Eastern Europe (CEE) was marked by the domination of domestic state-owned banks. Moreover, it was evident that domestic owners (mainly the state) did not adequately manage the assets of their companies, which resulted in the transformation of ownership structure and increased participation of foreign investors in the financial sector in the region. In a number of economic systems, especially in the case of the countries in the SEE region, there was an obvious trend of reduced participation of stated-owned banks in the system, as a result of: the opening of the national banking market for domestic and international equity, closing of banks burdened with losses and execution of the privatization policy [Marinković and Ljumović, 2011, p. 190].

Berger [2007] underlined the advantages and disadvantages of the entrance of foreign banks (financial institutions) onto the new markets. Some of the comparative advantages of foreign banks are: 
- Strane banke iz razvijenih zemalja koje ulaze na tržišta zemalja u razvoju bolje su u davanju kredita zasnovanih na informacijama koje se baziraju na kvalitetnim i poverljivim informacijama, kao rezultat njihove stručnosti i ekonomije obima.

- Kada strane banke iz razvijenih zemalja ulaze u zemlje u razvoju omogućava se transfer kapitala, znanja i iskustva najbolje prakse.

Sa druge strane, Berger navodi nedostatke u pogledu efikasnosti banaka (finansijskih institucija) u stranom vlasništvu:

- Privredno okruženje koje je bitno drugačije u odnosu na matičnu zemlju može uvećati troškove upravljanja i umanjiti efikasnost poslovanja banke.

- Multinacionalane kompanije daju prednost domaćim bankama za određene vrste servisa.

- Ukoliko se bitne odluke donose u sedištu banke, koje je na priličnoj udaljenosti u odnosu na lokalnu banku, ovo može prouzrokovati smanjnje efikasnosti poslovanja.

\section{Vlasnička transformacija bankarskog sektora pre izbijanja krize}

Početkom 2000. godine u bankarskom sistemu Republike Srbije dozvolu za rad su imale 84 banke, sa $90 \%$ učešća državnog kapitala u ukupnoj aktivi. Proces restrukturiranja domicilnog bankarskog sistema, imao je za posledicu, sa jedne strane, smanjenje ukupnog broja banaka, i broja banaka, u kojima je država većinski vlasnik, a sa druge strane, povećanja banaka kod kojih su vlasnici domaća i strana pravna lica [Mešić, 2006, str. 55]. Godine 2001. domicilni bankarski sektor je bio u većinskom državnom vlasništvu (65\% u poređenju sa $13 \%$ udela stranog kapitala).
U Hrvatskoj je disbalans u strukturi bio još očigledniji nego u Srbiji pa je tako vlasnička struktura aktive hrvatskog bankarskog sektora 1996. godine izgledala ovako: $80 \%$ učešća su imale banke u državnom vlasništvu, dok je samo $1 \%$ bio u rukama stranih vlasnika [Ćetković, 2011, str 8-9]. Ključne promene u pogledu vlasničke strukture u hrvatskom bankarskom sektoru su se dogodile 1999. godine kada je najveća banka (Zagrebačka banka) potpala pod većinsko strano vlasništvo (GDR $i$ EDR koji se vode kod Bankers Trust Company). Tokom 2000. godine druga, treća i četvrta banka su takođe privatizovane.

Proces transformacije vlasništva bankarskog sektora u Crnoj Gori intenziviran je početkom 2005. godine kada je Societe General banka investirala u Podgoričku banku. Godinu dana kasnije usledile su i privatizacije Pljevaljske, Nikšićke i Hipotekarne banke. Vlasništvo stranih banakarskih grupacija u Crnoj Gori je porasla sa $17 \%$ u 2002. godini na preko $90 \%$ u 2011. godini.

Na bankarskom tržištu u regionu centralne $i$ istočne Evrope prve se pojavljuju austrijske, nemačke i italijanske banke koje preuzimaju kreditne institucije u Češkoj, Hrvatskoj, Mađarskoj i Poljskoj. 
- Multinational activities of foreign-owned banks allow them to diversify risks in several regions where they perform business in order to minimize the costs connected to risk management.

- Banks monitor the business of their main corporate customers, and establish daughter banks in the countries into which their customers expand business.

- Geographical diversification of multinational banking business has a direct impact on the improvement of efficiency and profitability.

- Foreign banks from developed economies entering the emerging markets are better in granting loans on the basis of qualitative and reliable information, as a result of their expertise and economy of scale.

- Entrance of foreign banks from developed economies onto the emerging markets allows the transfer of equity, know-how and best practice.

On the other hand, Berger mentioned the following disadvantages of foreign-owned banks (financial institutions) in terms of efficiency:

- Business environment which is quite different comparing to the parent country can increase the managing costs and decrease the efficiency of a bank.

- Multinational companies give advantage to local banks for some services.

- If the decision making process is centralized, and the headquarters rather far away from the local bank, it can decrease the efficiency of the bank's business.

\section{Ownership transformation of the banking sector before the crisis}

In early 2000 the Serbian banking sector comprised 84 banks with an operating license, with $90 \%$ of state-owned banks in total assets. The result of the restructuring process went in two directions: 1) decreased number of all banks and banks whose main shareholder was the state, and 2) increased number of private-owned banks (with local and foreign ownership) [Mešić, 2006, p. 55]. In 2001, the domestic banking sector used to be mainly in the state-owned ownership (65\% comparing to $13 \%$ of foreign-owned local banks).
Table 1: Privatization of Serbian banks

\begin{tabular}{|l|c|c|c|}
\hline \multicolumn{1}{|c|}{ Name of the bank } & $\begin{array}{c}\text { Year of } \\
\text { the sale }\end{array}$ & Investor & $\begin{array}{c}\text { Selling price } \\
\text { (in EUR mil) }\end{array}$ \\
\hline Jubanka & 2003 & Alpha bank S.A. & 152,0 \\
\hline Novosadska banka & 2005 & Erste bank AG & 73,2 \\
\hline Continental banka & 2005 & NLB & 49,5 \\
\hline Nacionalna štedionica & 2005 & EFG bank & 44,4 \\
\hline Niška banka & 2006 & OTP bank & 14,2 \\
\hline Vojvođanska banka & 2006 & National Bank of Greece & 385,0 \\
\hline Panonska banka & 2006 & San Paolo Intesa & 112,0 \\
\hline
\end{tabular}

Source: Marinković S., Ljumović I., 2011, Effects of ownership transformation in the Serbian banking sector - theoretical and empirical analysis. Economic Themes 35, p. 197

The disbalance in the Croatian banking sector used to be even more obvious compared to the Serbian banking sector, which can be illustrated with the following ownership structure of assets in the Croatian banking sector in 1996: $80 \%$ of banks used to be state-owned, while only $1 \%$ used to be in foreign ownership [Ćetković, 2011, p 8-9]. The key changes related to ownership structure in the Croatian banking sector happened in 1999 when the biggest bank (Zagrebačka banka) went into majority foreign ownership (GDR and EDR registered with Bankers Trust Company). The second, the third and the fourth ranked Croatian banks were privatized during 2000.

The transformation process of the Montenegrin banking sector has been intensified since 2005 when Societe Generale bank invested in Podgorička bank. One year later, this was followed by the privatization of three relevant market players Pljevaljska, Nikšićka and Hipotekarna banks. The share of foreign ownership increased from $17 \%$ in 2002 to above $90 \%$ in 2011.

The first to enter the banking market of the CEE region were the Austrian, German and Italian banks which took over the credit institutions in Czech Republic, Croatia, Hungary and Poland. 
Tabela 2: Najveći akvizatori u bankarskom sektoru centralne i istočne Evrope (zaključno sa 2005. godinom)

\begin{tabular}{|l|l|l|c|}
\hline $\begin{array}{c}\text { Ime } \\
\text { akvizatora }\end{array}$ & $\begin{array}{c}\text { Zemlja } \\
\text { porekla } \\
\text { akvizatora }\end{array}$ & \multicolumn{1}{|c|}{ Zemlje targeta } & $\begin{array}{c}\text { Vrednost } \\
\text { transakcija } \\
\text { (u mlrd. evra) }\end{array}$ \\
\hline Erste bank & Austrija & $\begin{array}{l}\text { Hrvatska, Češka, Mađarska, } \\
\text { Rumunija, Srbija, Crna Gora, } \\
\text { Slovačka }\end{array}$ & 6,3 \\
\hline UniCredit & Italija & $\begin{array}{l}\text { Bugarska, Hrvatska, Češka, } \\
\text { Poljska, Turska }\end{array}$ & 2,5 \\
\hline $\begin{array}{l}\text { KBC/ } \\
\text { Almanji }\end{array}$ & $\begin{array}{l}\text { Belgija / } \\
\text { Holandija }\end{array}$ & Češka, Poljska, Mađarska, Slovenija & 2,4 \\
\hline Swedbank & Švedska & Estonija & 1,7 \\
\hline SocGen & Francuska & Češka, Rumunija, Rusija, Slovenija & 1,6 \\
\hline
\end{tabular}

Izvor: PricewaterhouseCoopers: European Banking Consolidation, april 2006

Godine 2005. u bankarskom sektoru Srbije, Rumunije, Hrvatske i Bosne i Hercegovine banke sa domaćim kapitalom još uvek su imale primat na tržištu, sa učešćem većim od $50 \%$. Međutim, u narednoj godini situacija je bitnije promenjena, budući da je 2006. godina bila zapamćena kao godina investicija putem kojih su se strane bankarske grupacije probile na ovo tržište. Da se vlasnička struktura na bankarskom tržištu potpuno izmenila govori podatak da je na domicilnom tržištu odnos domaćih prema stranim bankama išao u korist banka sa većinskim stranim kapitalom kojih je bilo 22 od ukupno 37. Situacija je bila slična i u Bosni i Hercegovini gde su strane kreditne institucije imale tržišni udeo od $60 \%$. Za razliku od Srbije i Bosne i Hercegovine, u Hrvatskoj su domaće banke uspele da se izbore na tržištu (18 domaćih banaka od ukupno 33 banke u 2006. godini). Do početka 2007. godine u Makedoniji su bile dominantne domaće banke sa učešćem od oko $60 \%$, dok je u narednim godinama zabeleženo povećanje tržišnog učešća stranih banka (iznad 70\%) i smanjenje broja banaka u domaćem vlasništvu.

$\mathrm{U}$ regionu centralne $\mathrm{i}$ istočne Evrope najznačajni investitori u bankarski sektor potiču iz Grčke i Austrije, a pored njih značajne su i banke sa zemljom porekla iz Francuske i Italije. Samo su grčki investitori do kraja 2005. godine uložili oko milijardu američkih dolara u bankarski sektor regiona. U periodu 2006-2007. najznačajnije merdžere i akvizicije u bankaskom sektoru zemalja u regionu sprovele su National Bank of Greece, Eurobank, Alpha Bank, ATE Bank,
Piraeus Bank [StojadinovićJovanović, 2013, str. 44].

\section{Vlasnička struktura i tržišno učešće stranih investitora $\mathbf{u}$ bankarskom sektoru u vreme krize}

Sa početkom svetske ekonomske krize i recesijom primećeno je smanjenje finansijske aktivnosti zapadnoevropskih kreditnih institucija $\mathrm{u}$ regionu jugoistočne Evrope. Ovaj trend je nastavljen, što je i razumljivo, budući da je broj atraktivnih banaka koje su bile pogodne za preuzimanje smanjen, da je ekonomski rast regiona usporen $i \mathrm{da}$ je $\mathrm{u}$ finansijskom sektoru prisutan deficit likvidnih sredstava. Najatraktivniji za ulaganje bio je bankarski sektor na kome su izvršena pripajajnja domaćih banaka kroz privatizacije ili merdžere i akvizicije inostranih sa domaćim bankama, dok su manje bile prisutne greenfield investicije. Podaci u tabeli 3 prikazuju broj banaka, njihovo tržišno učešće kao i učešće $u$ kapitalu/ bilansnoj sumi bankarskog sektora zavisno od toga da li je su u pitanju banke sa većinskim domaćim ili stranim vlasništvom u periodu 2007-2012. godina.

Narodna banka Srbije je od 2008. godine počela da objavljuje podataka o učešću stranih grupacija u kapitalu bankarskog sektora. $\mathrm{Na}$ domicilnom bankarskom tržištu u posmatranom periodu poslovalo je između 33 i 35 banaka, sa tržišnim učešćem banaka u većinskom stranom vlasništvu od oko $60 \%$. Tako je u posmatranom vremenskom razdoblju smanjeno tržišno učešće banaka sa većinskim domaćim kapitalom, što je dovelo do povećanja kako tržišne dominacije tako i do rasta učešća banaka sa stranim kapitalom. U proseku dvadesetak banaka sa većinskim stranim vlasništvom učestvovalo je u kapitalu bankarskog sektora u proseku sa oko $75 \%$, dok je oko 12 banaka u domaćem vlasništvu imalo učešće od $25 \%$. Najveće učešće u kapitalu ostvarile su italijanske banke (23\%), a sledile su ih austrijske (17\%), grčke $(15 \%)$ i francuske banke (8\%) [NBS, 2012].

$\mathrm{Na}$ kraju 2012. godine na bankarskom 
Table 2: The biggest acquisitions in the CEE banking sector (concluding with 2005)

\begin{tabular}{|l|l|l|c|}
\hline \multicolumn{1}{|c|}{$\begin{array}{c}\text { Buyer's } \\
\text { name }\end{array}$} & $\begin{array}{c}\text { Buyer's country } \\
\text { of origin }\end{array}$ & \multicolumn{1}{|c|}{ Target country } & $\begin{array}{c}\text { Transaction } \\
\text { value } \\
\text { (in EUR bil) }\end{array}$ \\
\hline Erste bank & Austria & $\begin{array}{l}\text { Croatia, Czech Republic, } \\
\text { Hungary, Romania, Serbia, } \\
\text { Montenegro, Slovak Republic }\end{array}$ & 6,3 \\
\hline UniCredit & Italy & $\begin{array}{l}\text { Bulgaria, Croatia, Czech } \\
\text { Republic, Poland, Turkey }\end{array}$ & 2,5 \\
\hline Almanji & $\begin{array}{l}\text { Belgium / } \\
\text { The Netherlands }\end{array}$ & $\begin{array}{l}\text { Czech Republic, Poland, } \\
\text { Hungary, Slovenia }\end{array}$ & 2,4 \\
\hline Swedbank & Sweden & Estonia & 1,7 \\
\hline SocGen & France & $\begin{array}{l}\text { Czech Republic, Romania, } \\
\text { Russia, Slovenia }\end{array}$ & 1,6 \\
\hline
\end{tabular}

Source: PricewaterhouseCoopers: European Banking Consolidation, April 2006

Eurobank, Alpha Bank, ATE Bank, Piraeus Bank [Stojadinović-Jovanović, 2013, p. 44].

\section{Ownership structure and market share of foreign investors in the banking sector during the crisis}

With the beginning of the global economic crisis and recession there was a prominent decrease of the financial activities in the Western European

In 2005 in the banking sector of Serbia, Romania, Croatia and B\&H the banks with domestic capital still had the primacy of the market, with the participation above 50\%. However, the situation significantly changed the next year, bearing in mind that 2006 was the year of investment through which foreign banking groups entered the market. That the ownership structure in the banking market completely changed is confirmed by the fact that on the domestic market the ratio of domestic-owned to foreign-owned banks was in favor of banks with majority foreign capital (22 out of the total of 37 banks). The situation was similar in $\mathrm{B} \& \mathrm{H}$ where foreign credit institutions had a market share of $60 \%$. As opposed to Serbia and B\&H, in Croatia the domestic-owned banks managed to cope on the market (18 locally owned banks out of the total number of 33 in 2006). By early 2007 in Macedonia the local-owned banks with a share of around $60 \%$ were dominant, while in the following years there was a noted increase in the market share of foreign-owned banks (over 70\%) and a reduction in the number of domestic-owned banks.

In CEE the most significant investors in the banking sector are from Greece and Austria, and besides them there are some important banks originating from France and Italy. By the end of 2005 the Greek investors invested about one billion of US dollars in the banking sector of the region. During the period 2006-2007 the most important M\&A in the banking sector were conducted by the National Bank of Greece, credit institutions in SEE the region. This trend was continued, quite understandably, since the number of attractive banks suitable for acquisition was reduced, the economic growth of the region slowed down and the financial sector recorded a deficit of liquid assets. The most attractive for investment was the banking sector, where mergers of domestic banks were performed through privatization or M\&A of foreign investors, with the minority presence of greenfield investments. The data in Table 3 represent the number of banks, their market share and share in capital/assets of the banking sector depending on whether they are banks with majority domestic or foreign ownership during the period 2007-2012.

The National Bank of Serbia started to publish the data on the share of foreign-owned groups in the banking sector capital in 2008. On the domestic banking market, in the reported period, there were between 33 and 35 operating banks, with the market share of majority foreign-owned banks amounting to about $60 \%$. Thus, in the reporting period the market share of banks with majority domestic-ownership was reduced, resulting in an increased market domination and increased share of banks with foreign capital. On average about twenty domestic banks with majority foreign ownership participated in the capital of the banking sector, with an average of about $75 \%$ while about 12 banks in domestic ownership had the share of $25 \%$. The largest share in capital was achieved by the Italian banks (23\%), 
tržištu Hrvatske poslovalo je ukupno 31 banka, 16 bankarskih grupacija sa većinskim stranim i 15 sa većinskim domaćim kapitalom. Iako su broj i tržišno učešće domaćih i stranih banaka približno izjednačeni, prema kriterijumu učešće u bilansnoj sumi, banke u većinskom stranom vlasništvu zabeležile su učešće iznad 90\%, te je 15 domaćih banaka učestvovalo samo sa $10 \%$ u ukupnoj aktivi. Drugim rečima, rastući trend stranog vlasništva u ukupnoj bilansoj sumu bankarskog sektora u Hrvatskoj za posledicu je imao povećanje stepena koncentracije kod ove grupe banaka.[CBH,2012]

Slična je situacija u Bosni i Hercegovini, budući da je u posmatranom periodu tržišno učešće banaka sa većinskim stranim kapitalom iznad $55 \%$, a učešće u aktivi više od $85 \%$.[Agencija za bankarstvo FBiH, 2012]
Analizirajući podatke bankarskog sektora u Crnoj Gori dolazimo do zaključka da se u posmatranom periodu broj banaka nije menjao, pri čemu je tržišno učešće banaka sa većinskim stranim vlasništvom bilo iznad $80 \%$. Učešće domaćih banaka u ukupnom kapitalu je imalo opadajući trend, da bi na kraju 2011. i 2012. godine dve domaće banke imale udeo od samo 10\%.[Centralna banka Crne Gore, 2012]

Specifičnost makedonskog bankarskog tržišta je izjednačeno tržišno učešće domaćih i banaka sa većinskim stranim kapitalom, ali i veće učešće stranih bankarskih grupacija u ukupnoj bilansnoj sumi bankarskog sektora u periodu 2008-2011 (oko 60\%) [Narodna banka Makedonije, 2012].

Tabela 3: Broj i tržišno učešće banaka sa većinskim domaćim i stranim kapitalom u zemljama jugoistočne Evrope

\begin{tabular}{|c|c|c|c|c|c|c|c|c|c|c|c|c|c|}
\hline & & \multicolumn{2}{|c|}{2007} & \multicolumn{2}{|c|}{2008} & \multicolumn{2}{|c|}{2009} & \multicolumn{2}{|c|}{2010} & \multicolumn{2}{|c|}{2011} & \multicolumn{2}{|c|}{2012} \\
\hline & & $\begin{array}{c}\% \\
\text { tržište }\end{array}$ & $\begin{array}{c}\% \\
\text { kapital }\end{array}$ & $\begin{array}{c}\% \\
\text { tržište }\end{array}$ & $\begin{array}{c}\% \\
\text { kapital }\end{array}$ & $\begin{array}{c}\% \\
\text { tržište }\end{array}$ & $\begin{array}{c}\% \\
\text { kapital }\end{array}$ & $\begin{array}{c}\% \\
\text { tržište }\end{array}$ & $\begin{array}{c}\% \\
\text { kapital }\end{array}$ & $\begin{array}{c}\% \\
\text { tržište }\end{array}$ & $\begin{array}{c}\% \\
\text { kapital }\end{array}$ & $\begin{array}{c}\% \\
\text { tržište }\end{array}$ & $\begin{array}{c}\% \\
\text { kapital }\end{array}$ \\
\hline \multirow{2}{*}{ SRB } & domaće & 40.0 & 22.7 & 41.2 & 20.9 & 41.2 & 22.3 & 36.4 & 29.0 & 36.4 & 25.0 & 33.3 & 26.0 \\
\hline & strane & 60.0 & 77.3 & 58.8 & 79.1 & 58.8 & 77.3 & 63.6 & 71.0 & 63.6 & 75.0 & 66.7 & 74.0 \\
\hline \multirow{2}{*}{$\mathrm{HRV}^{*}$} & domaće & 51.5 & 9.6 & 52.9 & 9.4 & 55.9 & 9.1 & 55.9 & 9.7 & 46.9 & 9,4 & 48.4 & 9.9 \\
\hline & strane & 48.5 & 90.4 & 47.1 & 90.6 & 44.1 & 90.9 & 44.1 & 90.3 & 53.1 & 90,6 & 51.6 & 90.1 \\
\hline \multirow{2}{*}{$\mathrm{BIH}$} & domaće & 45.5 & 17.0 & 40.0 & 11.6 & 40.0 & 10.8 & 42.1 & 17.5 & 42.1 & 12.7 & 38.9 & 9.0 \\
\hline & strane & 54.5 & 83.0 & 60.0 & 88.4 & 60.0 & 89.2 & 57.9 & 82.5 & 57.9 & 87.3 & 61.1 & 91.0 \\
\hline \multirow{2}{*}{ CG } & domaće & 18.2 & 24.0 & 18.2 & 20.0 & 18.2 & 19.0 & 18.2 & 12.0 & 18.2 & 10.0 & 18.2 & 10.0 \\
\hline & strane & 81.8 & 76.0 & 81.8 & 80.0 & 81.8 & 81.0 & 81.8 & 88.0 & 81.8 & 90.0 & 81.8 & 90.0 \\
\hline \multirow{2}{*}{ MAK $^{*}$} & domaće & 38.9 & 60.5 & 55.6 & 38.6 & 55.6 & 39.0 & 50.0 & 38.7 & 52.9 & 40.6 & 58.8 & 40.7 \\
\hline & strane & 61.1 & 39.5 & 44.4 & 61.4 & 44.4 & 61.0 & 50.0 & 61.3 & 47.1 & 59.4 & 41.2 & 59.3 \\
\hline \multirow{2}{*}{ RUM } & domaće & 14.3 & 12.0 & 14.0 & 11.8 & 16.7 & 14.7 & 16.7 & 15.0 & 17.1 & 17.0 & 19,0 & 10.1 \\
\hline & strane & 85.7 & 88.0 & 86.0 & 88.2 & 83.3 & 85.3 & 83.3 & 85.0 & 82.9 & 83.0 & 81,0 & 89.9 \\
\hline \multirow{2}{*}{ BUG } & domaće & 82.7 & 27.2 & 80.0 & 28.3 & 80.0 & 33.1 & 80.0 & 19.0 & 77.4 & 24.0 & 77.4 & 26.0 \\
\hline & strane & 17.2 & 72.8 & 20.0 & 71.7 & 20.0 & 66.9 & 20.0 & 81.0 & 22.6 & 76.0 & 22.6 & 74.0 \\
\hline \multirow{2}{*}{ ALB } & domaće & 6.0 & 8.7 & 6.0 & 8.1 & 6.0 & 6.9 & 12.5 & 7.9 & 12.5 & 9.7 & 87.5 & 10.2 \\
\hline & strane & 94.0 & 91.3 & 94.0 & 91.9 & 94.0 & 93.1 & 87.5 & 92.1 & 87.5 & 90.3 & 12.5 & 89.8 \\
\hline
\end{tabular}

* U hrvatskom i makedonskom bankarskom sektoru uzet je parametar učešće banaka u aktivi bankarskog sektora Izvor: Sajtovi centralnih banaka odabranih zemalja jugoistočne Evrope, Agencija za bankarstvo FBiH, BSCEE 
followed by the Austrian (17\%), Greek (15\%), and French banks (8\%) [NBS, 2012].

At the end of 2012 on the banking market of Croatia there were 31 operating banks, 16 foreign-owned banks and 15 domestic-owned banks. Although the number and market share of domestic and foreign-owned banks is almost equal, according to the criterion of share in total assets, foreign-owned banks recorded a share over $90 \%$, which means that the 15 domesticowned banks accounted for only $10 \%$ of total assets. In other words, the growing trend of foreign-owned banks in the total balance sheet of the banking sector in Croatia resulted in the increased level of concentration in this group of banks [CBH, 2012].

The situation was similar in $\mathrm{B} \& \mathrm{H}$, considering the fact that in the reported period the market share of foreign-owned banks was over $55 \%$, and asset participation was more than 85\% [Banking Agency FB\&H, 2012].

After analyzing the data about the banking sector in Montenegro we can conclude that in the reported period the number of banks did not change, while the market share of foreign-owned banks was above $80 \%$. The share of the domesticowned banks in the total capital had a decreasing trend, therefore at the end of 2011 and 2012 the two domestic-owned banks had a share of only 10\% [Central Bank of Montenegro, 2012].

The specificity of the Macedonian banking market is the equal market share of domestic and foreign-owned banks, but also a higher share of foreign banking groups in the total balance sheet of the banking sector during the period 2008-2011 (about 60\%) [National Bank of the Republic of Macedonia, 2012].

Table 3: Number and market share of domestic and foreign-owned banks in SEE countries

\begin{tabular}{|c|c|c|c|c|c|c|c|c|c|c|c|c|c|}
\hline & & \multicolumn{2}{|c|}{2007} & \multicolumn{2}{|c|}{2008} & \multicolumn{2}{|c|}{2009} & \multicolumn{2}{|c|}{2010} & \multicolumn{2}{|c|}{2011} & \multicolumn{2}{|c|}{2012} \\
\hline & & $\begin{array}{c}\text { Market } \\
\text { share } \\
\%\end{array}$ & $\begin{array}{l}\text { Share } \\
\text { in } \\
\text { capital } \\
\%\end{array}$ & $\begin{array}{c}\text { Market } \\
\text { share } \\
\%\end{array}$ & $\begin{array}{l}\text { Share } \\
\text { in } \\
\text { capital } \\
\%\end{array}$ & $\begin{array}{c}\text { Market } \\
\text { share } \\
\%\end{array}$ & $\begin{array}{l}\text { Share } \\
\text { in } \\
\text { capital } \\
\%\end{array}$ & $\begin{array}{c}\text { Market } \\
\text { share } \\
\%\end{array}$ & $\begin{array}{l}\text { Share } \\
\text { in } \\
\text { capital } \\
\%\end{array}$ & $\begin{array}{c}\text { Market } \\
\text { share } \\
\%\end{array}$ & $\begin{array}{l}\text { Share } \\
\text { in } \\
\text { capital } \\
\%\end{array}$ & $\begin{array}{c}\text { Market } \\
\text { share } \\
\%\end{array}$ & $\begin{array}{c}\text { Share } \\
\text { in } \\
\text { capital } \\
\%\end{array}$ \\
\hline \multirow{2}{*}{ SRB } & domestic & 40.0 & 22.7 & 41.2 & 20.9 & 41.2 & 22.3 & 36.4 & 29.0 & 36.4 & 25.0 & 33.3 & 26.0 \\
\hline & foreign & 60.0 & 77.3 & 58.8 & 79.1 & 58.8 & 77.3 & 63.6 & 71.0 & 63.6 & 75.0 & 66.7 & 74.0 \\
\hline \multirow{2}{*}{$\mathrm{CRO}^{*}$} & domestic & 51.5 & 9.6 & 52.9 & 9.4 & 55.9 & 9.1 & 55.9 & 9.7 & 46.9 & 9,4 & 48.4 & 9.9 \\
\hline & foreign & 48.5 & 90.4 & 47.1 & 90.6 & 44.1 & 90.9 & 44.1 & 90.3 & 53.1 & 90,6 & 51.6 & 90.1 \\
\hline \multirow{2}{*}{$\mathrm{B} \& \mathrm{H}$} & domestic & 45.5 & 17.0 & 40.0 & 11.6 & 40.0 & 10.8 & 42.1 & 17.5 & 42.1 & 12.7 & 38.9 & 9.0 \\
\hline & foreign & 54.5 & 83.0 & 60.0 & 88.4 & 60.0 & 89.2 & 57.9 & 82.5 & 57.9 & 87.3 & 61.1 & 91.0 \\
\hline \multirow{2}{*}{ MON } & domestic & 18.2 & 24.0 & 18.2 & 20.0 & 18.2 & 19.0 & 18.2 & 12.0 & 18.2 & 10.0 & 18.2 & 10.0 \\
\hline & foreign & 81.8 & 76.0 & 81.8 & 80.0 & 81.8 & 81.0 & 81.8 & 88.0 & 81.8 & 90.0 & 81.8 & 90.0 \\
\hline \multirow{2}{*}{ FYRM ${ }^{*}$} & domestic & 38.9 & 60.5 & 55.6 & 38.6 & 55.6 & 39.0 & 50.0 & 38.7 & 52.9 & 40.6 & 58.8 & 40.7 \\
\hline & foreign & 61.1 & 39.5 & 44.4 & 61.4 & 44.4 & 61.0 & 50.0 & 61.3 & 47.1 & 59.4 & 41.2 & 59.3 \\
\hline \multirow{2}{*}{$\mathrm{ROM}$} & domestic & 14.3 & 12.0 & 14.0 & 11.8 & 16.7 & 14.7 & 16.7 & 15.0 & 17.1 & 17.0 & 19,0 & 10.1 \\
\hline & foreign & 85.7 & 88.0 & 86.0 & 88.2 & 83.3 & 85.3 & 83.3 & 85.0 & 82.9 & 83.0 & 81,0 & 89.9 \\
\hline \multirow{2}{*}{ BUL } & domestic & 82.7 & 27.2 & 80.0 & 28.3 & 80.0 & 33.1 & 80.0 & 19.0 & 77.4 & 24.0 & 77.4 & 26.0 \\
\hline & foreign & 17.2 & 72.8 & 20.0 & 71.7 & 20.0 & 66.9 & 20.0 & 81.0 & 22.6 & 76.0 & 22.6 & 74.0 \\
\hline \multirow{2}{*}{ ALB } & domestic & 6.0 & 8.7 & 6.0 & 8.1 & 6.0 & 6.9 & 12.5 & 7.9 & 12.5 & 9.7 & 87.5 & 10.2 \\
\hline & foreign & 94.0 & 91.3 & 94.0 & 91.9 & 94.0 & 93.1 & 87.5 & 92.1 & 87.5 & 90.3 & 12.5 & 89.8 \\
\hline
\end{tabular}

* In the banking sector of CRO and FYRM the authors take the share in assets as an indicator. 
U poređenju sa analiziranim zemljama, rumunsko bankarsko tržište je u posmatranom periodu brojalo najviše igrača sa dominantnim učešćem stranih investitora kako u ukupnoj aktivi kao i u tržišnoj zastupljenosti (iznad 80\%) [Centralna banka Rumunije, 2012].

U Bugarskojje tržišniudeo banakau domaćem vlasništvu izraženiji, dok je, sa druge strane, učešće banaka sa većinskim stranim kapitalom u ukupnoj aktivi dominantno. Tako u 2012. godini, od ukupno 31 banke, sedam banaka sa većinskim stranim kapitalom imaju tržišno učešće od oko $23 \%$, dok je učešće u bilansnoj sumi bankarkog sektora 74\% [Narodna banka Bugarske, 2012].

Specifičnost albanskog bankarskog sektora ogleda se u nepromenjenom broju banaka kao i vlasničke strukture u periodu 2008-2012. godina, što potvrđuje statistika prema kojoj je učešće stranog i domaćeg kapitala u proseku bilo $90 \%$ prema 10\% u korist stranih investitora [Albanian Association of Banks, 2012].

Podaci pokazuju da se austrijski kapital, na prvom mestu Raiffeisen bank, nalazi u top pet vodećih banaka u većini zemalja jugoistočne Evrope. U Albaniji Raiffeisen bank zauzima prvu poziciju, u Bosni i Hercegovini drugu, dok je u Hrvatskoj bila četvoroplasirana. Pored Raiffeisen banke dosta visoko tržišno učešće su imale i Banca Intesa, UniCredit banka i Erste bank. Učešće grčkih banaka na bankarskom tržištu zemalja centralne i istočne Evrope procenjeno je na 20\% u 2009. godini [UNCTAD, 2010], pri čemu je najviši udeo primećen u bugarskom $(28,3 \%)$, rumunskom $(15,2 \%)$ i srpskom $(11,8 \%)$ bankarskom sektoru [Raiffeisen Research, 2010]. U ovim zemljama regiona banke sa većinskim grčkim kapitalom (EFG, National bank of Greece, Alpha bank) imale su između 1.000 i 1.200 otvorenih ekspozitura, koje na raspolaganju imaju 35\% kreditnih linija iz matičnih banaka, izuzetak su Hrvatska (Erste, Raiffeisen i Hypo bank posedovale su 1/3 bankarske imovine) $\mathrm{i}$ Rumunija u kojima su dominantne banke iz Austrije i Italije [EIB, 2013].

Intenziviranje dužničke krize u evrozoni u drugoj polovini 2011. godine imalo je veliki efekat na realni i na finansijski sektor $\mathrm{u}$ regionu. Značajno prisustvo stranih bankarskih grupacija rezultovalo je prelivanjem problema iz Evropske unije preko bankarskog sektora u zemljama u regionu.

Do kraja 2012, investicije iz Austrije, Italije i Francuske (koje predstavljaju 50\% ukupnog regionalnog učešća u evropskim banaka i $45 \%$ učešća $u$ regionu centralne $i$ istočne Evrope) dosegle su nivo iz 2009. godine. Međutim, ukoliko iz analize isključimo ove tri države možemo da konstatujemo da je interesovanje stranih investitora za ulaganje $\mathrm{u}$ bankarski sektor regiona smanjeno za $5 \%$ do $6 \%$ (u nekim slučajevima i za 20\%) u periodu 20092012 [Popovici, 2012, str. 573-574]. Tako je udeo nemačkih, belgijskih i grčkih banaka u regionu smanjen sa $30 \%$ na oko $25 \%$ u poslednjih nekoliko godina.

U tabeli 4 dat je prikaz izvršenih preuzimanja u bankarskom sektoru u zemljama centralne i istočne Evrope u periodu 2013-2014. godina. 
In comparison to the analyzed countries, the Romanian banking market within the reported period counted the largest number of players with the dominant share of foreign investors, both in total assets and in market share (over $80 \%$ ) [National Bank of Romania, 2012].

In Bulgaria the share market of domesticowned banks is more prominent, while on the other hand, the share of foreign-owned banks in total assets is dominant. Thus in 2012, out of 31 banks, seven banks with foreign-owned equity had the market share of about $23 \%$, while the share in the total balance sheet size of the banking sector was 74\% [Bulgarian National Bank, 2012].

The specificity of the Albanian banking sector is reflected in the unchanged number of banks as well as the ownership structure during the period 2008-2012, as evidenced by the statistics according to which the share of the foreign and domestic-owned banks in the banking sector's capital was on average about $90 \%$ versus $10 \%$ in favor of foreign investors [Albanian Association of Banks, 2012].

The data show that the Austrian capital, in the first place that of Raiffeisen bank, is among the top five banks in most SEE countries. In Albania Raiffeisen bank held the first place, in B\&H it was the second, while in Croatia it was the fourth-ranked bank. In addition to Raiffeisen bank, banks with a rather high market share are Banca Intesa, UniCredit bank and Erste bank. The share of the Greek banks in the banking market of CEE countries is estimated at $20 \%$ in 2009 [UNCTAD, 2010], whereby the highest share was observed in the Bulgarian (28.3\%), Romanian (15.2\%) and Serbian (11.8\%) banking sector [Raiffeisen Research, 2010]. In these countries the banks with majority Greek capital (EFG, National Bank of Greece, Alpha bank) have between 1,000 and 1,200 open branch offices, with $35 \%$ credit lines from mother banks at their disposal, the exceptions being Croatia (Erste, Raiffeisen and Hypo bank with $1 / 3$ of banking assets in their possession) and Romania with dominant banks from Austria and Italy [EIB, 2013].

The intensification of the Eurozone debt crisis in the second half of 2011 had a major influence on the real and financial sector in the region. The important presence of foreign banking groups resulted in the spillover of problems in the EU onto the banking sectors in the regional countries.

By the end of 2012, investments from Austria, Italy and France (representing 50\% of total regional share in the European banks and $45 \%$ in the CEE region) reached the level from 2009. However, if we exclude these three countries from research we can conclude that the interest of foreign investors for investing in the regional banking sectors was reduced by $5 \%$ to $6 \%$ (in some cases up to $20 \%$ ) during the period 2009-2012 [Popovici, 2012, pp. 573-574]. Thus, the share of the German, Belgian and Greek banks in the region was reduced from $30 \%$ to $25 \%$ in the last few years.

Table 4 gives an overview of finalized acquisitions in the CEE banking sector during the period 2013-2014. 
Tabela 4: Izvršena preuzimanja u bankarskom sektoru u zemljama centralne $\mathrm{i}$ istočne Evrope $\mathrm{u}$ periodu 2013-2014. godina

\begin{tabular}{|c|c|c|c|}
\hline Zemlja & $\begin{array}{l}\text { Target za } \\
\text { preuzimanje }\end{array}$ & $\begin{array}{l}\text { Ukupna aktiva } \\
\text { (u mlrd. evra) }\end{array}$ & Komentar \\
\hline BUG & $\begin{array}{l}\text { MKB } \\
\text { Unionbank }\end{array}$ & 0,8 & $\begin{array}{l}\text { Bugarska First Investment Bank je preuzela } \\
100 \% \text { akcija MKB Unionbank za } 50 \text { miliona } \\
\text { evra. }\end{array}$ \\
\hline \multirow{4}{*}{ RUM } & $\begin{array}{l}\text { RBS retail } \\
\text { operations }\end{array}$ & 0,3 & $\begin{array}{l}\text { UniCredit je preuzeo portfolio } \\
\text { stanovništva i privatnog bankarstva RBS } \\
\text { banke na proleće } 2013 \text {. godine. }\end{array}$ \\
\hline & RIB & 0,1 & $\begin{array}{l}\text { Getin Holding je kupoprodao banku } 2013 . \\
\text { godine. }\end{array}$ \\
\hline & Nextebank & 0,2 & $\begin{array}{l}\text { U decembru 2013. godine Axxess Capital je } \\
\text { otkupio Nextebank od } M K B \text { (čiji je vlasnik } \\
\text { bio BayernLB). }\end{array}$ \\
\hline & $\begin{array}{l}\text { Citibank } \\
\text { operations }\end{array}$ & 0,1 & $\begin{array}{l}\text { U prvom kvartalu 2013. godine Raiffeisen } \\
\text { Bank Romania otkupila je depozite } \\
\text { stanovništva za } 90 \text { miliona evra. }\end{array}$ \\
\hline \multirow{2}{*}{ SRB } & KBC banka & 0,1 & $\begin{array}{l}\text { Mobilni operater Telenor je otkupio } 100 \% \\
\text { akcija (kupovina licence), dok je Societe } \\
\text { Generale banka preuzela kreditni portfolio. }\end{array}$ \\
\hline & Aik banka & 1,3 & $\begin{array}{l}\text { Miodrag Kostić je povećao udeo akcija sa } \\
36 \% \text { na } 50,4 \% \text { u februaru } 2014 \text {. godine. }\end{array}$ \\
\hline HRV & $\begin{array}{l}\text { Banco } \\
\text { Popolare }\end{array}$ & 0,3 & $\begin{array}{l}\text { U januaru 2014. godine OTP banka } \\
\text { Hrvatska preuzela je } 100 \% \text { vlasništvo nad } \\
\text { Banco Popolare po ceni od } 13 \text { miliona evra. }\end{array}$ \\
\hline $\mathrm{BIH}$ & $\begin{array}{l}\text { Balkan } \\
\text { Investment } \\
\text { Bank }\end{array}$ & n.a. & $\begin{array}{l}\text { Vlada Republike Srpske preuzela je Balkan } \\
\text { Investment Bank AD Banja Luka po ceni od } \\
15 \text { miliona evra. }\end{array}$ \\
\hline
\end{tabular}

Izvor: Raiffeisen Research, CEE banking sector report, maj 2014, str. 74-75

je učešće $u$ bilansnoj sumi banaka sa većinskim stranim kapitalom do osam puta veće.

- Crnoj Gori dominantna pozicija banaka sa većinskim stranim vlasništvom, koje imaju skoro devet puta veće učešće u ukupnom kapitalu u odnosu na banke sa domaćim kapitalom.

- Makedoniji broj banaka sa stranim i domaćim kapitalom izjednačen, pri čemu prva grupa banaka ima dominantan položaj kada je u pitanju učešće u ukupnoj bilansnoj sumi bankarskog sektora.

- Rumuniji prisutno pet puta više banaka u stranom nego u domaćem vlasništvu, koje imaju do osam puta veći udeo u kapitalu.

- Bugarskoj situacija

Najatraktivnija za ulaganje je bila Rumunija, gde su izvršena četiri preuzimanja u bankarskom sektoru, zatim Srbija sa dva, dok je u Bugarskoj, Hrvatskoj i Bosni i Hercegovini bila atraktivna po jedna banka za preuzimanje.

\section{Zaključak}

Zapadnoevropske bankarske grupacije su u jugoistočnoj Evropi doživele ekspanziju što potvrđuju pokazatelji bankarske aktive (ili kapitala), koja se nalazi u vlasništvu stranih banaka u odnosu na ukupnu aktivu (ili kapital) bankarskog sektora. Tako je u:

- Srbiji na tržištu duplo više banaka sa većinskim stranim kapitalom, koje imaju tri puta veće učešće u kapitalu.

- Hrvatskoj broj banaka sa stranim i domaćim kapitalom izjednačen, pri čemu je učešće u bilansnoj sumi banaka sa većinskim stranim kapitalom do deset puta veće.

- Bosni i Hercegovini broj banaka sa stranim i domaćim kapitalom izjednačen, pri čemu drugačija budući da banke u većinskom domaćem vlasništvu imaju do četiri puta veće tržišno učešće. Međutim, Bugarska je dobar primer koji prikazuje da bez obzira na broj učesnika na tržištu, banke u većinskom stranom vlasništvu ostvaruju veći udeo $u$ kapitalu u odnosu na domaće banke.

- Albaniji prisutna skoro apsolutna dominacija banaka sa većinskim stranim vlasništvom (iznad 90\%) kada je reč o tržišnom učešću kao i u učešću u kapitalu.

$\mathrm{Na}$ osnovu sprovedene analize i iznetih podatka $\mathrm{u}$ vezi sa bankarskim sektorom $\mathrm{u}$ analiziranom regionu možemo da konstatujemo da je hipoteza u istraživanju potvrđena.

U svim zemljama (osim u Bugarskoj, delimično u Makedoniji i Hrvatskoj) prisutno je značajno veće učešće stranih banaka $u$ ukupnom broju banaka, ali u svim zemljama je zabeleženo značajno veće učešće banaka u većinskom stranom vlasništvu u ukupnoj aktivi (kapitalu). 
Table 4: Finalized transactions in the banking sector in SEE countries in 2013-2014

\begin{tabular}{|c|c|c|c|}
\hline Country & Target & $\begin{array}{c}\text { Total assets } \\
\text { (EUR bill) }\end{array}$ & Comment \\
\hline \multirow{2}{*}{ SRB } & KBC banka & 0.1 & $\begin{array}{l}\text { Mobile operator Telenor bought } 100 \% \text { of the } \\
\text { shares (i.e. license), while the local SocGen } \\
\text { subsidiary took over the loan portfolio. }\end{array}$ \\
\hline & Aik banka & 1.3 & $\begin{array}{l}\text { Miodrag Kostić increased his holding to } 50.4 \% \\
\text { from } 36 \% \text { via a takeover bid in February } 2014 \text { at } \\
\text { a price of approx. } 0.3 \times \text { BV. }\end{array}$ \\
\hline $\mathrm{CRO}$ & Banco Popolare & 0.3 & $\begin{array}{l}\text { In January } 2014 \text { OTP Bank Croatia acquired } \\
100 \% \text { of Banco Popolare Croatia at a price of } \\
\text { EUR } 13 \text { mill. }\end{array}$ \\
\hline \multirow{4}{*}{ ROM } & $\begin{array}{l}\text { RBS retail } \\
\text { operations }\end{array}$ & 0.3 & $\begin{array}{l}\text { UniCredit took over the retail \& private banking } \\
\text { portfolio of RBS in Romania in the spring of } \\
2013 .\end{array}$ \\
\hline & RIB & 0.1 & $\begin{array}{l}\text { Getin Holding bought the bank from two } \\
\text { individuals in late } 2013 \text {. }\end{array}$ \\
\hline & Nextebank & 0.2 & $\begin{array}{l}\text { Three investment funds managed by Axxess } \\
\text { Capital bought Nextebank from MKB (which is } \\
\text { owned by BayernLB) in December } 2013\end{array}$ \\
\hline & $\begin{array}{l}\text { Citibank } \\
\text { operations }\end{array}$ & 0.1 & $\begin{array}{l}\text { Raiffeisen Bank Romania acquired the retail loan } \\
\text { book of EUR } 90 \text { mill as well as deposits/Asset } \\
\text { under Management in Q1 } 2013 \text {. }\end{array}$ \\
\hline $\mathrm{B} \& \mathrm{H}$ & $\begin{array}{l}\text { Balkan Investment } \\
\text { Bank }\end{array}$ & n.a. & $\begin{array}{l}\text { The Government of the Republic of Serbia } \\
\text { acquired the Balkan Investment Bank AD Banja } \\
\text { Luka for EUR } 15 \text { mill. }\end{array}$ \\
\hline
\end{tabular}

Source: Raiffeisen Research, CEE banking sector report, 2014, p. 74-75

the participation of foreign-owned banks in total assets is up to eight times greater.

- I n

Montenegro the dominant position is set by foreignowned banks, having an almost nine times bigger share in the total capital compared to domesticowned banks.

- In Macedonia the number of foreign and domestic-owned banks is equal, whereby the first group of banks has a dominant position when it comes to the share

The most attractive for investment was Romania, where they made four acquisitions in the banking sector, followed by two acquisitions in Serbia, while Bulgaria, Croatia and B\&H had one acquisition each.

\section{Conclusion}

The Western European banking groups have experienced an expansion in the SEE countries as evidenced by indicators of banking assets (or capital), owned by foreign banks in relation to total assets (or capital) of the banking sector. Thus:

- In Serbia there are twice more banks with foreign-owned equity, with a three times higher share in the capital.

- In Croatia the number of foreign and domestic-owned banks is equal, whereby the participation of foreign-owned banks in total assets is up to ten times greater.

- In B\&H the number of domestic and foreign-owned banks is equal, whereby in the banking sector's total assets.

- In Romania there is five times more foreignowned than domestically owned banks, which have an up to eight times higher capital share.

- In Bulgaria the situation is different because domestic-owned banks have up to four times higher market share. However, Bulgaria is a good example, illustrating that regardless of the number of market participants, foreignowned banks have a higher capital share compared to domestic-owned banks.

- In Albania there is an absolute predominance of foreign-owned banks (over 90\%) in terms of market share and capital share.

Based on the research conducted and the banking sector data presented about the analyzed region, we can conclude that the hypothesis of the study has been confirmed.

In all countries (except in Bulgaria, partially in Macedonia and Croatia) there is a significantly greater share of foreign-owned banks in total assets (and capital) of the banking sector. 


\section{Literatura / References}

1. Agencija za bankarstvo FBiH. Skraćeni izveštaj vanjskih revizora o finansijskim iskazima banaka u $\mathrm{FBiH}$. preuzeto 14 . februara 2016. sa sajta: http://www.fba.ba/ index.php?page $=37$

2. Albanian Association of Banks. Banking System Monthly Bulletin, preuzeto 22. januara 2016. sa sajta: http://www.aab.al/ en/statistics.php

3. Banking Supervisors from Central and Eastern Europe. preuzeto 22. januara 2016. sa sajta: https://www.bscee.org/publications/ review.html

4. Barjaktarović L., Paunović M. 2012. ,Komparativna analiza bankarskog sektora u zemljama centralne i istočne Evrope sa osvrtom na Srbiju. Anali Ekonomskog fakulteta 48, (28): 83-96

5. Berger A.N. 2007. Obstacles to a global banking system: Old Europe versus new Europe. Journal of banking and finance 3, (7), 1960-1962

6. Berger A.N. 2007. International comparisons of banking efficiency, Financial markets, institutions and instruments 16, (3), 129-133

7. Bonin J.P. 2004. Banking in the Balkans: the structure of banking sectors in Southeast Europe. Economic systems.28, (2), 141-153

8. Centralna banka Crne Gore,.Bilten Centralne banke Crne Gore. preuzeto 18. februara 2016. sa sajta: http://www.cb-mn.org/index. php?mn1=publikacije\&mn2=bilten_cbcg

9. Centralna banka Hrvatske. Bilten o bankama. preuzeto 20. januara 2016. sa sajta: http://www.hnb.hr/analize-i-publikacije/ redovne-publikacije/bilten-o-bankama
10. Centralna banka Rumunije. Monthly Bulletin of NBR. preuzeto 12. februara 2016. sa sajta: http://www.bnr.ro/PublicationDocuments. aspx?icid $=6851$

11. Ćetković P. 2011.Credit growth and instability in Balkan countries: the role of foreign banks, Research on money and finance, Discussion paper no. 27

12. Dinkić M., Jelašić R. 2001. Strategija restrukturiranja bankarskog sistema, Narodna banka Jugoslavije

13. Erić Jović M. 2012. Banke i osiguranja u Srbiji 2001-2011, poređenje sa zemljama u regionu, U: Erić Jović, M., Bankarski sektor Srbije 2001-2011, reforme, oporavak i novi izazovi, Business Info Group, preuzeto 15. februara 2016. sa sajta: http://www.big. co.rs/upload/Edition/Download/2013-06/ Banke_I_Osiguranja_U_Srbiji_2001_2011_I_ Poredjenje_Sa_Zemljama_Regiona.pdf

14. European Central Bank. EU Banking structure 2010. preuzeto 1 . februara 2016. sa sajta: https://www.ecb.europa.eu/pub/pdf/ other/eubankingstructures201009en.pdf

15. European Investment Bank EIB. 2013. Banking in Central and Eastern Europe and Turkey - Challenges and opportunities. preuzeto 10. februara 2016. sa sajta: http:// www.eib.org/attachments/efs/economic report_banking_cee_turkey_en.pdf

16.IMF, World Economic Outlook 2012. preuzeto 26. januara 2016. sa sajta: https:// www.imf.org/external/pubs/ft/weo/2012/02/ pdf/text.pdf 
17. Kraft E.R., Hofler J.P. 2006. Privatization, foreign bank entry and bank efficiency in Croatia: a Fourier-flexible function stochastic cost frontier analysis. Applied economics.38, 2075-2088

18. Macut M. 2014. Savremeni trendovi u bankarstvu- segment poslova sa stanovništvom. Anali Ekonomskog fakulteta 50, (31), 198-199

19. Marinković S., Ljumović I. 2011. Efekti vlasničke transformacije bankarskog sektora Srbije - teorijska i empiriska analiza. Ekonomske teme 35, (1), 198-208

20. Matić V. 2014. Finansije srpske. Udruženje banaka Srbije, 225-259

21. Mešić D. 2006. Ulazak stranih banaka u zemlje u tranziciji, Bankarstvo 7-8, 48-58

22. Narodna banka Bugarske. Banks in Bulgaria. preuzeto 2. marta 2016. sa sajta: http://www.bnb.bg/BankSupervision/ BSCreditInstitution/BSCIRegistrers/BS_CI_ REG_BANKSLIST_EN

23. Narodna banka Makedonije. Report on banking system of the Republic of Macedonia. preuzeto 5. februara 2016. sa sajta: http://www.nbrm.mk/default.asp?Ite $\mathrm{mID}=4810081475 \mathrm{BC} 6 \mathrm{~F} 49 \mathrm{~A} 2 \mathrm{AB} 0716 \mathrm{ED} 9 \mathrm{CB}$ ED3
24. Narodna banka Srbije. Izveštaj za IV tromesečje 2012. godine. preuzeto 15. januara 2016. sa sajta: http://www.nbs.rs/export/ sites/default/internet/latinica/55/55_4/ kvartalni_izvestaj_IV_12.pdf

25. Popovici A.N. 2012.Mergers, acquisition and banking consolidation in Central and Eastern Europe, CES Working Papers 5, (4), 573-574

26. Raiffeisen Research. 2010. CEE banking sector report. preuzeto 25. februara 2016. sa sajta: http://www.rzb.at/eBusiness/services/ resources/media/677012584775275435_677251119927032833_677257048341086064679588600387211306-1-9-DE.pdf

27. Stojadinović-Jovanović S. 2013. Strane direktne investicije kao oblik finansiranja globalne ekonomije. Bankarstvo 1, 34-57

28. United Nations Conference on Trade and Development UNCTAD. 2010. World investment report: Cross-border mergers and acquisitions and development. Geneva 